\title{
Working
}

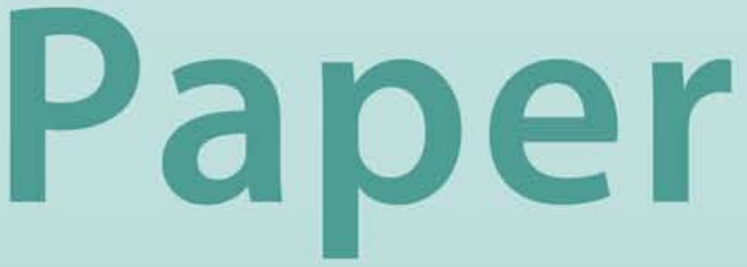


Economic Integration and Financial Stability: A European Perspective

Gianni De Nicolò and Alexander Tieman 


\title{
IMF Working Paper
}

\section{Economic Integration and Financial Stability: A European Perspective}

\author{
Prepared by Gianni De Nicolò and Alexander Tieman ${ }^{1}$ \\ Authorized for distribution by Laura Kodres and Kal Wajid
}

December 2006

\begin{abstract}
This Working Paper should not be reported as representing the views of the IMF. The views expressed in this Working Paper are those of the author(s) and do not necessarily represent those of the IMF or IMF policy. Working Papers describe research in progress by the author(s) and are published to elicit comments and to further debate.

This paper assesses changes in synchronization of real activity and financial market integration in Western Europe and evaluates their implications for financial stability. We find increased synchronization of real activity since the early 1980s and increased equity markets integration since the early 1990s. We also find that measures of systemic risk at large European financial institutions have not declined during the period 1990-2004 and that bank systemic risk profiles have converged. At the same time, the sensitivity of bank and insurance systemic risk measures to common real and financial shocks has increased in most countries. Overall, these results suggest that the integration process does not necessarily entail an unambiguously positive effect on financial stability.
\end{abstract}

JEL Classification Numbers:F36, G21, G22

Keywords: Financial stability, Economic integration, Europe.

Author’s E-Mail Addresses: gdenicolo@imf.org; atieman@imf.org.

\footnotetext{
${ }^{1}$ Research Department and Monetary and Capital Markets Department, respectively. We thank Robert Corker, Bob Flood, Ayan Kose, Til Schuermann, Boris Vujcic, and participants to IMF seminars, the DG-ECFIN 2005 Research Conference, and the XIV Tor Vergata Conference, for comments and suggestions. Excellent research assistance by Marianne El-Khoury is gratefully acknowledged.
} 


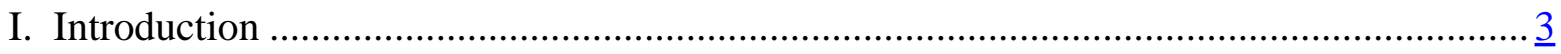

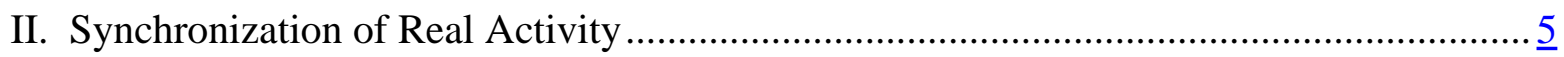

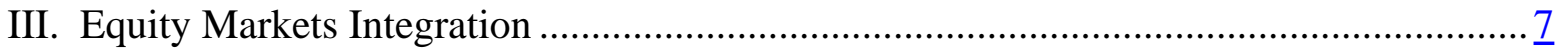

IV. Systemic Risk and Integration ....................................................................... $\underline{9}$

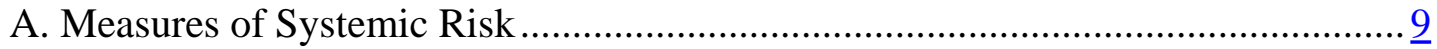

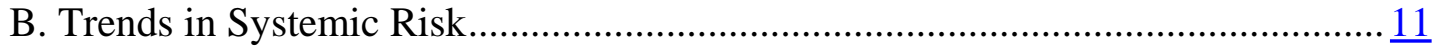

C. Convergence of Systemic Risk Measures ..................................................... 12

D. The Sensitivity of Systemic Risk Measures to Real and Financial Shocks ........... 13

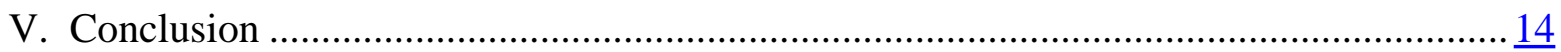

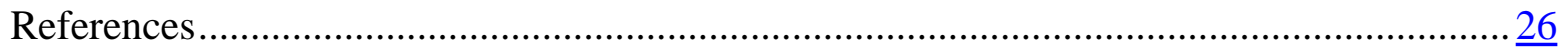

Tables

1. EGARCH Estimates for the Common Components of IPG …............................. 16

2. EGARCH Estimates for Cross-Country Variances of IPG and De-Trended IPG ...... $\underline{17}$

3. Country-by-Country EGARCH Estimates for IPG .............................................. $\frac{18}{19}$

4. Dependent Variables: Cross-Country Variance of IEDFs and Country IEDFs......... $\underline{19}$

5. Dependent Variable: Cross-Country Variance of Portfolios’ DDs........................... 21

6. Dependent Variable: Banks DDs Changes ..................................................... 22

7. Dependent Variable: Insurance DDs Changes................................................. 23

Appendix Tables

A1. Banks and Insurance Companies ...................................................... 24

Figures

1. EGARCH Estimates of IPG Common Component ........................................ $\frac{16}{20}$

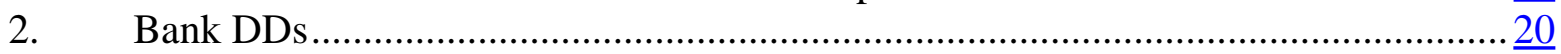

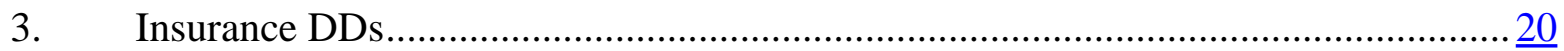




\section{INTRODUCTION}

Research on synchronization of real activity and financial integration in Europe has intensified in the past few years. Nevertheless, the implications of integration for financial stability remain largely unexplored. This paper aims at contributing to fill in this gap.

Structural changes in the environment in which financial firms operate, such as increased real synchronization and advances in financial integration, may affect individual and system-wide risk profiles of financial intermediaries differentially (see De Nicolò and Kwast, 2002, and De Nicolò and others, 2004e). On the one hand, enhanced synchronization in real activity may reduce the benefits of cross-country diversification. If either the shocks hitting a set of economies (and the relevant borrowers) become more similar, or the transmission mechanism of country-specific shocks becomes stronger, or both, then the pool of diversifiable (credit and market) risks available to intermediaries may shrink. On the other hand, financial integration may enhance diversification opportunities for individual intermediaries, which can rely on enlarged investment opportunities across activities and borders to enhance expected returns for the same amount of risk. Yet, a set of intermediaries may become less diversified as a whole if their exposures to the same risks increase, either by choice or because the sources of "aggregate" risk have become more similar. Moreover, increased linkages among intermediaries through enhanced common exposures to financial markets may make their exposure to contagion more likely.

Disentangling these possibly countervailing effects on financial stability is the main task of this paper. Accomplishing this task requires first assessing whether increases in real synchronization and advances in financial integration have indeed occurred, since the existing literature does not offer unequivocal answers. Second, it requires constructing measures of systemic risk, and relating them to outcomes of changes in real synchronization and financial integration.

With regard to real synchronization, several studies have attempted to identify a "European business cycle," but research on the existence of such an object is still ongoing; as a result, few studies have focused on changes in real synchronization. ${ }^{2}$ Moreover, this literature has dealt almost exclusively with fluctuations of GDP and/or industrial production growth rates. As our focus is on the impact of changes in real synchronization on the risk profiles of financial institutions through their portfolio choices, synchronization of volatility of growth rates of real activity may be as important, if not more important, than synchronization in levels.

\footnotetext{
${ }^{2}$ For recent reviews of the literature, see Stock and Watson (2005) and Kose, Otrok, and Whiteman (2005). Persistence in business cycles heterogeneity within Europe is stressed by Artis (2003).
} 
With regard to financial integration, recent studies have documented increased convergence in prices of money and bond markets, while noting the slower pace of price convergence in retail bank credit markets (Barros and others, 2005; Baele and others, 2004; and Adam and others, 2002). However, the literature exhibits mixed results concerning the integration of equity markets. As stressed by Adjaouté and Danthine (2004), a difficulty in assessing integration lies in disentangling pricing effects from changes in fundamentals. Yet, we view an assessment of advances in equity market integration as a robust gauge of advances in financial integration more generally, since equity markets are ones in which claims on a large variety of countries' investment opportunities are traded, and integration in such markets does not necessarily follow mechanically from cross-country convergence of interest rates.

We proceed in three steps. First, we assess cross-country convergence of the first and second moments of output growth. The consideration of second moments is novel, and turns out to be informative on the changing nature of common versus country-specific driving forces of the dynamics of real activity. Second, we test whether cross-country convergence of estimates of a discount factor used to price "idiosyncratic" risks in equity markets has occurred, employing a version of the methodology introduced by Flood and Rose (2005).

Finally, we document the dynamics of proxy measures of systemic risk based on data for a set of large European banks and insurance companies in the past 15 years. We test convergence in both levels and volatility of these dynamics, and assess whether the risk profiles of these financial institutions have become more sensitive to common real and financial shocks. In doing so, we view the sensitivity of financial institutions' risk profiles to common real and financial shocks as a useful metric to gauge the implications of increased synchronization in real activity and advances of financial integration through the overall exposure of intermediaries to "common” market and credit risks.

Our investigation yields three main sets of results. First, we find evidence of increased synchronization in the dynamics of real activity since the early 1980s, in the form of declining trends in the cross-country dispersion in the mean and volatility of industrial production monthly growth rates. These declining trends are found after controlling for common shocks, whose magnitude has become smaller, and are mainly driven by business cycle synchronization. Second, we find evidence of increased equity markets integration since the early 1990s, in the form of a declining trend in the cross-country dispersion of expected discount factors estimated in each of the European equity markets considered.

Third, we find lack of evidence of a decline in risk profiles for European banks and insurance companies during the period 1990-2004. Importantly, we find that these risk profiles have converged, and that the sensitivity of bank risk profiles to both common real and financial shocks has significantly increased. An interpretation of these findings is that increased synchronization in real activity and advances in financial integration may have reduced the benefits of cross-country diversification.

The remainder of the paper consists of three sections. Section II assesses synchronization in real activity, while Section III considers integration of equity markets. Section IV constructs 
indicators of system-wide financial risk for a set of systemically important banks and insurance companies in a large set of European countries, and relates the dynamics of these measures to the outcomes of increased real synchronization and advanced financial integration. Section V concludes.

\section{SyNCHRONIZATION OF REAL ACTIVITY}

We gauge changes in synchronization of real activity by the evolution of the cross-country dispersion in the first and second conditional moments of seasonally adjusted monthly industrial production growth (IPG) for the 10 European countries for which we have complete data for the period 1961:01-2004:12. ${ }^{3}$ Subject to an important qualification detailed below, a downward trend in the dynamics of the cross-country variance of IPG and its country-specific volatility may capture increased synchronization in real activity, as this indicates increased correlation of the IPG series in the sample. ${ }^{4}$ A statistical model for such dynamics is obtained as follows.

Let $X_{i t}$ denote IPG in country $i$ at date $t . X_{i t}$ turns out well described by the following E(xponential)GARCH(1,1) model:

$$
\begin{aligned}
& X_{i t}=\alpha_{i t}+\beta_{i} F_{t}+\gamma X_{i t-1}+h_{i t} \varepsilon_{i t} \\
& \operatorname{Ln}\left(h_{i t}^{2}\right)=a_{i t}+b \varepsilon_{i t-1}^{2}+c \operatorname{Ln}\left(h_{i t-1}^{2}\right)
\end{aligned}
$$

The term $F_{t}$ in the mean Equation (1) is a risk factor common to all countries. The variance Equation (2) describes the evolution of country-specific volatility. As customary, the innovations $\varepsilon_{i t}$ are assumed to be i.i.d. and normally distributed with zero mean and unit variance.

We take a weighted average of IPG rates as a proxy measure of the common component of IPG rates. Thus, we set $F_{t}=\sum_{i} w_{i t} X_{i t} / N$. This common component is measured using the time-varying weights proposed by Lumsdaine and Prasad (2003), where $w_{i t} \equiv \tilde{h}_{i t}^{-1} / \sum_{i} \tilde{h}_{i t}^{-1}$,

\footnotetext{
3 These countries are: Austria, Belgium, France, Germany, Greece, Italy, Netherlands, Portugal, Sweden, and the United Kingdom. All results we obtain for first moments hold when we use quarterly GDP growth data instead of IPG data.

${ }^{4}$ As shown in Solnik and Roulet (2000), under the assumption that the data generating process for a sufficiently large set of variables is described by a factor model, the evolution of their cross-sectional dispersion is inversely related to their pairwise correlation.
} 
and variances $\tilde{h}_{i t}$ are obtained by estimates of model (1)-(3) without the common factor. This specification embeds the assumption that the relative conditional standard deviation is a measure of the degree of commonality of countries' real fluctuations.

Stock and Watson (2005) have documented a reduction in the volatility of G-7 business cycles, and argued that this has been associated with a reduction in the magnitude of common shocks. Have reductions of volatility and the magnitude of common shocks occurred in Europe? The answer is affirmative. Note that by construction, $F_{t}$ is described by an EGARCH(1,1) model. As shown in Figure 1, the estimated conditional variance and the residuals of both series appear to exhibit a downward trend. Furthermore, we tested for such a downward trend by estimating the EGARCH model for $F_{t}$ with a trend both in the mean and variance equations. As shown in Table 1, the coefficient of the time trend in the conditional mean and variance is negative and highly significant.

To obtain a model for the cross-country variance of IPG and its volatility, note that the conditional mean and variance of $X_{i t}$ are given by $m_{t-1}\left(X_{i t}\right) \equiv \alpha_{i t}+\beta_{i} E_{t-1} F_{t}+\gamma X_{i t-1}$ and by $\operatorname{var}_{t-1}\left(X_{i t}\right) \equiv \beta_{i}^{2} \sigma_{F}^{2}(t)+h_{i t}^{2}$ respectively. Assume that the coefficients $\left\{\alpha_{i t}, \beta_{i}, a_{i}\right\}$ are distributed cross-sectionally with means $\left\{\alpha_{t}, \beta, a\right\}$ and variances $\left\{\sigma_{\alpha t}^{2}, \sigma_{\beta}^{2}, \sigma_{a}^{2}\right\}$, and that covariances among all these random variables, as well as that of $X_{i t-1}$ and $F_{t}$ and each of these are approximately nil. Under these assumptions, the cross-sectional variances of $m_{t-1}\left(X_{i t}\right)$ and $h_{i t}^{2}$ are given by

$$
\begin{aligned}
& \sigma_{X}^{2}(t) \equiv E\left(m_{t-1}\left(X_{i t}\right)-E m_{t-1}\left(X_{i t}\right)\right)^{2}=\sigma_{\alpha t}^{2}+\sigma_{\beta}^{2}\left(E_{t-1} F_{t}\right)^{2}+\gamma^{2} \sigma_{X}^{2}(t-1) \\
& \sigma_{h^{2}}^{2}(t) \equiv E\left(h_{i t}^{2}-E h_{i t}^{2}\right)^{2}=\sigma_{a t}^{2}+b^{2} \sigma_{\varepsilon^{2}}^{2}(t-1)+c^{2} \sigma_{h^{2}}^{2}(t-1)
\end{aligned}
$$

Increased synchronization in real activity occurs if $\sigma_{\alpha t}^{2}$ and/or $\sigma_{a t}^{2}$ exhibit a declining path. Note that a decline in $\sigma_{X}^{2}(t)$ exclusively driven by a decline in the magnitude of common shocks $\left(\left(E_{t-1} F_{t}\right)^{2}\right)$ (which we have shown above has occurred) would not necessarily indicate increased integration, since disconnected economies hit by the same shock would exhibit the same decline.

We estimate the following counterpart of model (3)-(4) :

$$
\begin{aligned}
& \bar{\sigma}_{X}^{2}(t)=A_{0}+A_{1} t+A_{2}\left(E_{t-1} F_{t}\right)^{2}+A_{3} \bar{\sigma}_{X}^{2}(t-1)+H_{t} \eta_{t} \\
& \log H_{t}^{2}=B_{0}+B_{1} t+B_{2} \eta_{t-1}^{2}+B_{3} \log H_{t-1}^{2}
\end{aligned}
$$

Two measures for $\bar{\sigma}_{X}^{2}(t)$ are used. The first one is the sample cross-sectional variance of IPG rates. The second one is the variance of deviations of IPG of each country from its own trend, 
obtained by applying the relevant HP filter. ${ }^{5}$ This second measure is used to gauge the extent to which detrended and non-detrended dynamics differ. For both measures, we test whether $A_{1}$ and/or $B_{1}$ are negative.

Table 2 reports estimates of model (5)-(6). Both the trend coefficients in the mean equation (6) and the variance equation (7) are negative and significant. Moreover, the estimates of these coefficients remain virtually unchanged when the cross-sectional variance of deviations of IPG from trend is used. Most important, the relevant trend coefficients remain negative but become highly significant. This indicates that business cycle convergence is the primary driver of the decreasing dispersion of IPG rates. Notably, increased synchronization has occurred not only in the form of increased correlation of IPG fluctuations across countries, but also in terms of increased correlation of their (country-specific) volatilities.

To gauge the approximate timing of increased synchronization, we estimated model (1)-(2) for each country with dummies for different decades in both the mean and variance equations. As shown in Table 3, increased synchronization in the form of a decline of the cross-country variance of IPG rates started to occur in the early 1980s By contrast, the crosscountry dispersion in the variance of IPG volatility does not exhibit a decline. This result, coupled with the significant decline found earlier, suggests that convergence in volatility is either driven by a subset of countries in the sample or has occurred at different points in time in some countries, or both.

Summing up, synchronization in real activity appears to have increased since the early 1980s. It has been primarily driven by increases in business cycle synchronization, and is not the mechanical outcome of a decline in the magnitude of common shocks.

\section{EQUITY MARKETS INTEGRATION}

One difficulty in testing advances in equity market integration rests on disentangling pricing effects from the effects of fundamental shocks. Here we tackle this problem by using a version of the methodology proposed by Flood and Rose (2005) (FR henceforth), which exploits the pricing of "idiosyncratic risk," as opposed to systematic risk. As detailed below, an advantage of this methodology is that it does not require taking a stand on a particular asset pricing model.

Consider the standard intertemporal asset pricing equation:

$$
p_{t}^{j}=E_{t}\left(m_{t+1} x_{t+1}^{j}\right)=\operatorname{COV}_{t}\left(m_{t+1}, x_{t+1}^{j}\right)+E_{t} m_{t+1} E_{t} x_{t+1}^{j}
$$

\footnotetext{
${ }^{5}$ For data at monthly frequency, here and in the sequel we use the value of the smoothing parameter for the HP filter derived by Ravn and Uhlig (2002), equal to 129,600.
} 
where $p_{t}^{j}$ is the price of asset $j$ at date $t, E_{t}$ is the expectations operator, $C O V_{t}$ is the covariance operator conditional on information available at date $t$, and $m_{t+1}$ is the rate used to discount the income $x_{t+1}^{j}$ accruing to the holder of the asset at date $t+1$. Equation (8) can be re-written as:

$$
x_{t+1}^{j}=\delta_{t}\left(p_{t}^{j}-\operatorname{COV}_{t}\left(m_{t+1}, x_{t+1}^{j}\right)\right)+\varepsilon_{t+1}^{j},
$$

where $\delta_{t} \equiv 1 / E_{t} m_{t+1}$ is the inverse of the expected discount factor (IEDF), and $\varepsilon_{t+1}^{j} \equiv x_{t+1}^{j}-E_{t} x_{t+1}^{j}$ is a prediction error orthogonal to information available at date $t$. If all assets traded in a given market are discounted at the same rate, then such asset market is said to be integrated.

As our focus is not on assessing integration per se, but changes in integration, we take the dynamics of the cross-country variance of estimated IEDFs across different equity markets as our measure of changes in integration. If markets become increasingly integrated, this variance should decline. If they moved towards perfect integration, this variance should converge to zero.

Estimates of IEDFs are obtained as follows. Let the time series vector $Z_{t}$ denote the set of factors that capture all systematic components of (log) returns. Then, $p_{t}^{j}=p_{t-1}^{j} \exp \left(\beta^{\prime} Z_{t}+v_{t}^{j}\right)$, where $v_{t}^{j}$ is the idiosyncratic part of asset $j$ return. Following FR, define the "systematic price" $\tilde{p}_{t}^{j}$ as the value of $p_{t}^{j}$ conditional on idiosyncratic information available at date $t$ set to zero. Thus, $\tilde{p}_{t}^{j} \equiv p_{t-1}^{j} \exp \left(\beta^{\prime} Z_{t}\right)$. Normalizing equation (8) by such price yields:

$$
\left.x_{t+1}^{j} / \tilde{p}_{t}^{j}=\delta_{t}\left(p_{t}^{j} / \tilde{p}_{t}^{j}\right)-\delta_{t} \operatorname{COV}_{t}\left(m_{t+1}, x_{t+1}^{j} / \tilde{p}_{t}^{j}\right)\right)+\varepsilon_{t+1}^{j}=\delta_{t} \exp \left(v_{t}^{i}\right)+u_{t+1}^{j}
$$

where $u_{t+1}^{j} \equiv \varepsilon_{t+1}^{j}-\delta_{t} \operatorname{COV}_{t}\left(m_{t+1}, x_{t+1}^{j} / \tilde{p}_{t}^{j}\right)$.

Estimates of the IEDF $\delta_{t}$ can thus be obtained through regressions (9) by means of the following two-step procedure. In the first step, the "systematic price” $\tilde{p}_{t}^{j}$ of value weighted industry portfolios for each stock market is estimated by OLS, using the set of principal components of returns to factor out systematic risks. Their number is identified by standard statistical procedures. In the second step, returns are normalized with the estimated systematic price $\hat{p}_{t}^{j}$, and the IEDF estimates for each equity market and date are obtained by means of OLS cross-sectional regressions of the type:

$$
x_{t+1}^{j} / \hat{p}_{t}^{j}=c_{t}+\delta_{t} \exp \left(v_{t}^{i}\right)+u_{t+1}^{j}
$$


As stressed by Marshall (2005), the constant is needed to control for date-specific (aggregate) shocks that can still be embedded into the IEDF estimates. This estimation procedure was applied to the 13 sectoral portfolios and 9 countries for which monthly data from Datastream were available for the 1975:01-2004:12 period. $^{6}$

All IEDF estimates exhibit correlation with future returns and first-order autocorrelation not significantly different from zero. They also exhibit high volatility, but standard tests reject the hypothesis of ARCH effects. It turns out that the dynamics of the IEDFs for country $i$ at date $t$, denoted by $M_{i t}$, is well represented by a simple random walk with drift. Thus, we gauge whether equity markets integration has advanced by testing the significance of a time trend in the following equation for the cross-country variance of IEDFs, denoted by $\bar{\sigma}_{M}^{2}(t)$ :

$$
\bar{\sigma}_{M}^{2}(t)=A_{0}+A_{1} t+\eta_{t}
$$

Table 4 reports estimates of (11), specified with a time trend as well as with a set of decadelong dummies. As shown in Panel A, the trend coefficient is negative and significant. As shown in Panel B, increased integration appears to have occurred approximately since the early 1990s. This is also confirmed by simple tests of differences in slopes associated with decade-long dummies. As shown in Panel C, these results are further validated by estimated time trends for the IEDF for each country, since the cross-country variance of the decadelong dummies exhibits a decline from the early 1990s.

In sum, European equity market integration appears to have advanced since the early 1990s. This result is consistent with the conjectures advanced by Adjaouté and Danthine (2004), and with the finding of Baele and others (2004), who document European stock returns and volatility as increasingly affected by "common” European shocks.

\section{SYSTEMIC RISK AND INTEGRATION}

\section{A. Measures of Systemic Risk}

Our indicators of systemic risk are distance-to-default (DD) measures of "portfolios" of sets of publicly traded, systemically important European banks and insurance companies. These measures are based on the structural valuation model of Black and Scholes (1973) and

\footnotetext{
6 The sectors covered are: Banks, Insurance, Financials, Non-Financials, Basic Industries, Cyclical Consumer Goods, Cyclical Services, General Industrials, Information Technology, Non-Cyclical Services, Non-Cyclical Consumer Goods, Resources, and Utilities. The countries are: Austria, Belgium, Denmark, France, Germany, Ireland, Italy, Netherlands, and the United Kingdom. In all first step regressions, the first two principal components were sufficient to capture common risks according to standard statistical criteria.
} 
Merton (1974) (BSM hereafter). ${ }^{7}$ In the BSM model, the portfolio's equity is viewed as a call option on the portfolio's assets, with strike price equal to the current book value of total liabilities. When the value of the portfolio's assets is less than the strike price, its equity value is zero. The market value of assets is not observable, but can be estimated using equity values and accounting measures of liabilities.

Under the assumption that asset values follow a lognormal process, the DD of a portfolio of $N$ firms (indexed by $i$ ) is given by:

$$
D D_{t}=\frac{\operatorname{Ln}\left(V_{t}^{P} / L_{t}^{P}\right)+\left(\mu_{P}-0.5 \sigma_{P}^{2}\right)}{\sigma_{P}}
$$

where $V^{P}=\sum_{i} V_{t}^{i}$ and $L_{t}^{P}=\sum_{i=1}^{N} L_{t}^{i}$ are the total value of assets and liabilities, respectively. The mean and variance of the portfolio are respectively given by $\mu_{P}=\sum_{i} w_{t}^{i} \mu^{i}$ and $\sigma_{P}=\sum_{i} \sum_{j} w_{t}^{i} w_{t}^{j} \sigma_{i j}$, where $w_{t}^{i}=V_{t}^{i} / \sum_{i} V_{t}^{i}$ and $\sigma_{i j}$ is the asset return covariance of firm $i$ and $j$. Thus, the "portfolio” DD embeds the structure of risk interdependencies among firms. "Default" at date $t+1$ occurs when $V_{t}^{P}<L_{t}^{P}$. Thus, the DD indicates how many standard deviations $\operatorname{Ln}\left(V_{t}^{P} / L_{t}^{P}\right)$ has to deviate from its mean in order for default to occur. Since $V_{t}^{P}=L_{t}^{P}+E_{t}^{P}$, where $E_{t}^{P}$ is the value of equity, declines in $V_{t}^{P} / L_{t}^{P}$ imply declines in capitalization $\left(E_{t}^{P} / L_{t}^{P}\right)$.

Lower (higher) levels of the “portfolio” DD imply a higher (lower) probability of firms” joint failure. Since positive and negative variations in the DD of individual firms are allowed to offset each other, the DD of a portfolio is always higher than the (weighted) sum of the DDs of the individual firms. ${ }^{8}$ As a result, the probability of "failure" associated with the "portfolio" DD is always lower than that associated with the actual probability of joint failures of sets of firms in the portfolio. Thus, the "portfolio" DD can be viewed as tracking the evolution of a lower bound to the joint probabilities of failure of the firms composing a portfolio. For this reason, and because of the distributional assumptions underlying its derivation, ${ }^{9}$ the portfolio DD measure is a conservative measure of systemic risk, that is, it is likely to underestimate systemic risk.

\footnotetext{
7 Risk measures obtained from structural models, such as the BSM model, have been shown to have predictive power for supervisory ratings, bond spreads, and rating agencies’ downgrades as well as actual defaults (see Krainer and Lopez, 2001; Gropp, Vesala, and Vulpes, 2006; Arora, Bohn and Zhu, 2005; and Tarashev, 2005).

8 This fact can be also seen as an implication of Jensen’s inequality.

${ }^{9}$ Recall that under the assumption that asset values follow a lognormal process, DD measures do not necessarily capture extreme events adequately. In addition, the simplifying assumption that the liability structure is composed of only equity and debt with fixed maturity for all firms, and no rollover of debt, may lead to underestimates of interest rate risks and other risks associated with contingent (derivative) liabilities.
} 
We constructed portfolios for all banks and insurance companies included in the relevant Datastream indexes during the period 1991.01-2004.12. ${ }^{10}$ The monthly DD measures were estimated using the methodology described in Vassalou and Xing (2004). At each date, the value of asset, the return on assets and its volatility were derived using the option valuation formula of the BSM model, using one year of daily equity return data preceding the estimation date, and the accounting value of liabilities for the relevant year. This procedure was repeated for each month, and the relevant estimates were used to construct the "portfolio" DD measures at a monthly frequency. As shown by Duan, Gauthier and Simonato (2004), this procedure yields maximum likelihood estimates of implied asset returns and volatility.

\section{B. Trends in Systemic Risk}

Figure 2 depicts the evolution of bank systemic risk measures and their trend computed applying an HP filter. Over the period 1990-2004, bank systemic risk does not appear to have declined.

One explanation of these dynamics rests on the changes in the composition of sources of income that have occurred during the period examined. European banks exhibited a substantial increase in noninterest income in the past decade (ECB, 2004). As documented in De Nicolò and others (2005), the volatility of noninterest income growth was significantly larger than that of interest income growth at large banks since 1997. Moreover, the correlation between interest and noninterest income growth has been high ( 0.79 for the EU-15), indicating decreasing diversification benefits across traditional and nontraditional business lines. As banks' earnings have increasingly relied on income generated through financial market activity, most large banks have experienced significant increases in asset return volatility since the early 1990s. Substantial increases in capitalization and improvements in returns have occurred as well, but they have not been sufficient to offset increases in asset return volatility. Thus, large European banks may have supported higherrisk/higher-return investments with larger capital buffers. Yet, risk-adjusted asset returns have not increased, and overall risk profiles have not declined. Using a different systemic risk metrics but a smaller sample of European financial institutions, Hartmann, Straetmans and de Vries (2005) provide further evidence consistent with our results.

These findings, and the attendant interpretation, do not characterize only European banks. A similar pattern appears to have characterized the evolution of risk profiles of U.S. banks as well, as documented by De Nicolò, Hayward, and Vir Bhatia (2004) for U.S. large complex banking groups, and by Stiroh (2004), Hartmann, Straetmans, and de Vries (2005), Stiroh and Rumble (2006), and Houston and Stiroh (2006) for a large set of U.S. bank holding companies, using different systemic risk metrics. Using a term aptly coined by Stiroh and

\footnotetext{
${ }^{10}$ As of end-2004, the Datastream indices included 63 banks and 53 insurance companies, whose identities and asset sizes are reported in the Appendix.
} 
Rumble, the "dark side of diversification" has materialized for U.S. banks as well during the same period.

The dynamics of systemic risk profiles for insurance companies is depicted in Figure 3. While in most European countries these dynamics are similar to those of banks, crosscountry heterogeneity is more marked. In some instances, the systemic risk measures indicate that a decline has occurred recently.

\section{Convergence of Systemic Risk Measures}

Hartmann, Straetmans and de Vries (2005) provide evidence of increased systemic risk in the 1990s for a set of large European (and U.S.) banks in the form of increased correlation of measures of extreme realizations of bank stock excess returns. Unlike these measures, our measures of systemic risk are directly related to firms' joint probability of failures, since they take into account not only the evolution of bank returns, but also their volatility and firms' capitalization. Do our measures of systemic risk point at increased correlation in the form of convergence? The answer is affirmative.

We test convergence in both levels and volatility of our systemic risk measures. Denote the sample cross-sectional variance of "portfolio" DDs by $\bar{\sigma}_{D D}^{2}(t)$. We posit and estimate the following EGARCH-type model for $\bar{\sigma}_{D D}^{2}(t)$ :

$$
\begin{aligned}
& \bar{\sigma}_{D D}^{2}(t)=A_{0}+A_{1} t+A_{2} Y_{t}^{2}+A_{3} \bar{\sigma}_{D D}^{2}(t-1)+H_{t} \eta_{t} \\
& \log H_{t}^{2}=B_{0}+B_{1} t+B_{2} \eta_{t-1}^{2}+B_{3} \log H_{t-1}^{2}
\end{aligned}
$$

As remarked previously, assessing convergence requires controlling for the magnitude of common shocks, since financial firms operating in totally disconnected economies may exhibit increased comovements in their risk profiles just because the economies in which they operate are hit by the same shock. This motivates the introduction of a proxy measure of "common" risks in the mean equation (12), which is simply measured by the average of

each country financial sector DD, $Y_{t}=\sum_{i} D D_{i t} / N$. Convergence in systemic risk profiles of the banks and insurance sectors is assessed by testing whether the coefficients $A_{1}$ and/or $B_{1}$ are negative.

Table 5 reports estimates of model (12)-(13). Bank systemic risk profiles exhibit convergence in both mean and the variance, since the trend coefficients are negative and highly significant in both the mean and variance equations. These results provide strong support to the conjecture that risk interdependencies have increased remarkably. By contrast, insurance risk profiles do not exhibit convergence either in the mean or in the variance. In sum, convergence in systemic risk profiles has occurred for banks, but there is no evidence that it has occurred for insurance companies. 


\section{The Sensitivity of Systemic Risk Measures to Real and Financial Shocks}

Have increased real synchronization and advances in financial markets integration affected the dynamics of systemic risk profiles? We address this question by assessing whether the sensitivity of risk profiles of banks and insurance companies to both real and financial shocks common to all countries considered has significantly increased. The impact of such shocks is simply proxied by the common component of real activity estimated previously, and by a value-weighted index of European stock market returns.

An increased sensitivity of the dynamics of systemic risk profiles to the common component of real activity would indicate a greater impact of common real shocks to institutions' exposures, in part due to increased synchronization of real activity. Similarly, an increased sensitivity of these profiles to common financial shocks may be a result of increased financial integration. This is supported by our results on convergence in European IEDFs, as well as by the increased correlation of European stock market returns documented by Bekaert, Hodrick, and Zhang (2005),

Changes in these sensitivities are gauged as follows. Let $\rho_{t}^{i} \equiv D D_{i t}-D D_{i t-1}$ denote monthly changes in the DD for banks and insurance sectors in country $i$. Standard tests for $\rho_{t}^{i}$ reject ARCH effects for both banks and insurance companies. We estimate a version of the following simple model for $\rho_{t}^{i}$ in each country:

$$
\rho_{t}^{i}=\alpha+\beta_{1}(t) F_{t}+\beta_{2}(t) R_{t}+\gamma \rho_{t-1}^{i}+\varepsilon_{t}
$$

where $F_{t}$ denotes the common component of real activity estimated previously, and $R_{t}$ denotes the Datastream European stock market index. Variables $F_{t}$ and $R_{t}$ are likely to capture distinct sources of real and financial shocks, since their contemporaneous correlation was only 0.06 during the entire 1991.1-2004.12 period.

We wish to test whether the coefficients $\beta_{1}(t)$ and $\beta_{2}(t)$ have increased. Given the short length of the sample, regressions (14) are simply estimated allowing these coefficients to differ for three periods approximately four-years long: 1991.1-1994.12, 1995.1-1998.12, and 1999.1-2004.12.

Table 6 reports regressions (14) for banks, where the coefficients for the three periods considered are denoted by $\beta_{1 j}$ and $\beta_{2 j}, j=1,2,3$, and the relevant indicator functions $I_{j}, j=1,2,3$. The sensitivity of bank systemic risk measures to common shocks has increased in all countries but Austria, Greece, Italy, and Norway, where it has remained approximately constant. In most cases, the relevant coefficients have turned from negative to positive, and significantly so. By contrast, the sensitivity of bank risk profiles to financial shocks has changed differently across countries, increasing in Austria, France, Germany, Greece, Italy, 
the Netherlands, and Portugal, but decreasing in Belgium, Ireland, Norway, Spain, Sweden, and the United Kingdom.

The results for insurance companies are similar to those for banks with respect to common real risks, but exhibit heterogeneity with respect to financial risks. As shown in Table 7, the sensitivity of insurance systemic risk measures to common real shocks has increased in all countries but Austria, Denmark, Italy, and the United Kingdom, where it has remained approximately constant. On the other hand, the sensitivity to financial shocks has increased in France Germany, Italy, and the Netherlands, but has decreased in Denmark, Ireland, and Norway.

Summing up, we find a significant increase in the sensitivity of bank systemic risk profiles to real shocks. In no country have such sensitivities have declined. We also find a significant increase in the sensitivities to financial shocks for institutions located in all large countries but Spain and the United Kingdom. The results for insurance risk profile mirror those for banks with regard to increased exposures to common real shocks, but exhibit heterogeneity with respect to common financial shocks. However, the sensitivity of insurance risk profiles to both common real and financial shocks has increased for most institutions located in the largest countries.

\section{CONCLUSION}

In this paper we have assessed whether synchronization in real activity has increased and equity market integration has advanced, and have examined one dimension through which systemic risk profiles at large, systemically important European banks and insurance companies may have been affected by changes in real synchronization and financial markets integration.

We found increased synchronization of real activity starting in the early 1980s, and increased integration in the equities markets starting in the early 1990s. We also found that our measures of bank systemic risk profiles have not declined over the last 15 years, and have converged both in levels and volatility. This evidence suggests that banks may have opted for investment strategies targeting higher-risk/higher-expected returns.

Furthermore, we assessed whether the sensitivity of bank and insurance systemic risk profiles to common real and financial shocks have changed during this period. We found that for banks, the sensitivity of risk profiles to common real and financial shocks has significantly increased in most countries. The sensitivity of risk profiles of insurance companies to common real shocks has significantly increased as well in most countries, while their sensitivity to common financial shocks appears to have increased only for institutions located in the large continental European countries.

Overall, these findings suggest that increased real synchronization and advances in financial integration may not have necessarily resulted in heightened financial stability. Thus, enhanced monitoring of increased interdependencies in risk profiles among institutions and 
through markets appears an important task European supervisors may face as integration progresses. 
Figure 1: EGARCH estimates of IPG Common Component
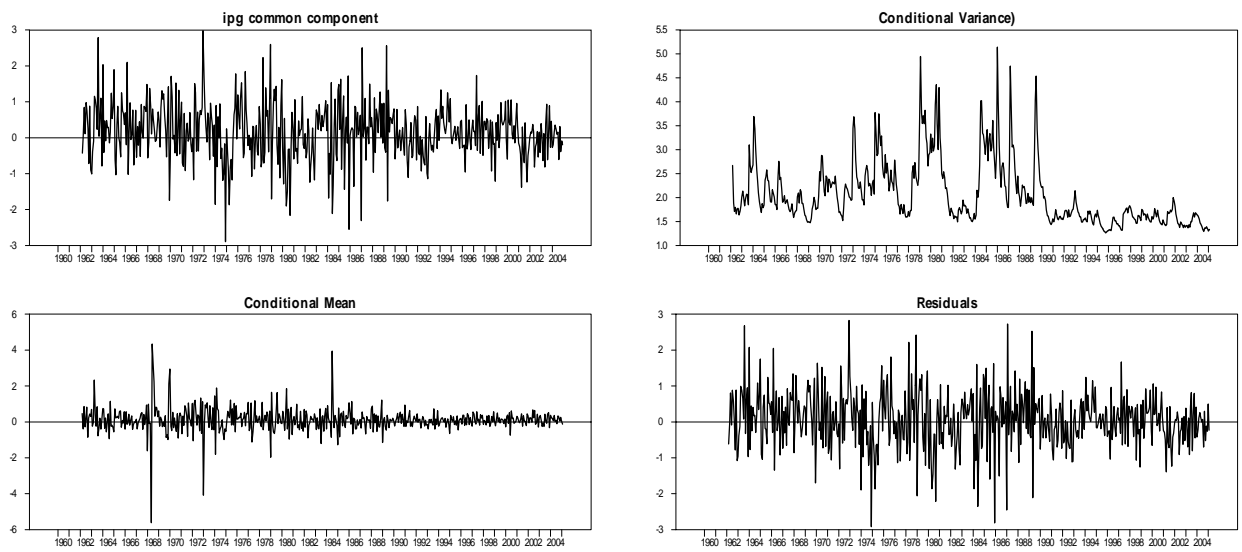

Table 1. EGARCH Estimates for the Common Components of IPG

Mean Equation: $\quad F_{t}=A_{0}+A_{1} t+A_{2} F_{t-1}+H_{t} \eta_{t}$

Variance Equation: $\quad \log H_{t}^{2}=B_{0}+B_{1} t+B_{2} \eta_{t-1}^{2}+B_{3} \log H_{t-1}^{2}$

\begin{tabular}{lrrrr}
\hline & Coefficients & Standard Error & T-Statistic & p-value \\
\hline Mean Equation & & & & \\
A0 & 0.33118 & 0.07129 & 4.64574 & 0.00000 \\
A1 & $\mathbf{- 0 . 0 0 0 5 7}$ & $\mathbf{0 . 0 0 0 1 8}$ & $\mathbf{- 3 . 2 2 8 9 6}$ & $\mathbf{0 . 0 0 1 2 4}$ \\
A2 & 0.03188 & 0.03612 & 0.88267 & 0.37741 \\
Variance Equation & & & & \\
B0 & -0.15833 & 0.19829 & -0.79851 & 0.42457 \\
B1 & $\mathbf{- 0 . 0 0 2 6 7}$ & $\mathbf{0 . 0 0 0 7 6}$ & -3.51361 & $\mathbf{0 . 0 0 0 4 4}$ \\
B2 & 0.38005 & 0.08970 & 4.23701 & 0.00002 \\
B3 & -0.12188 & 0.24345 & -0.50065 & 0.61662
\end{tabular}


Table 2. EGARCH Estimates for Cross-Country Variances of IPG and De-Trended IPG

Mean Equation: $\quad \bar{\sigma}_{X}^{2}(t)=A_{0}+A_{1} t+A_{2}\left(E_{t-1} F_{t}\right)^{2}+A_{3} \bar{\sigma}_{X}^{2}(t-1)+H_{t} \eta_{t}$

Variance Equation: $\quad \log H_{t}^{2}=B_{0}+B_{1} t+B_{2} \eta_{t-1}^{2}+B_{3} \log H_{t-1}^{2}$

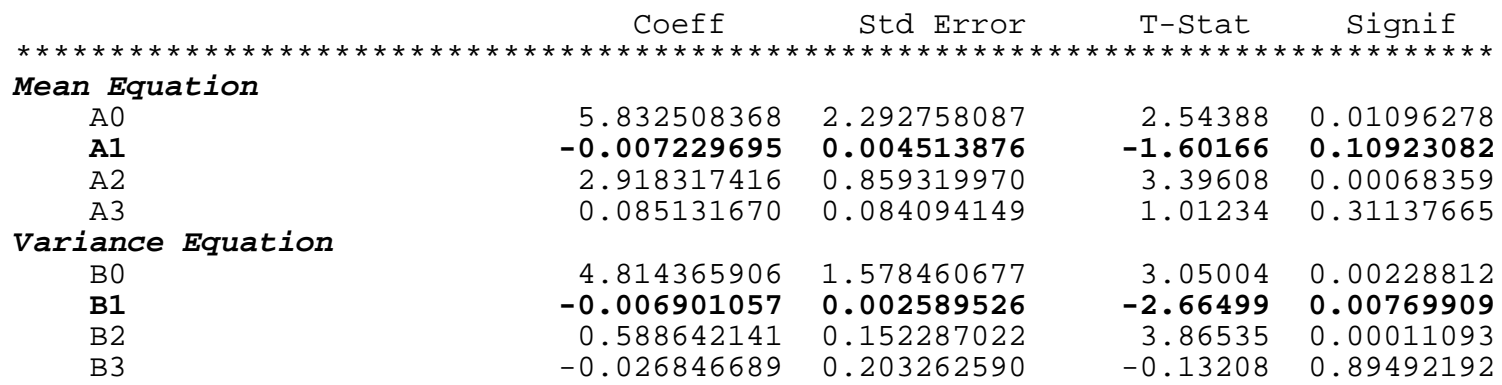

Mean Equation
A0
A1
A2
A3
Variance equation
B0
B1
B2
B3

\section{De-trended}

$\begin{array}{rr}5.303880223 & 0.950224807 \\ -0.006814521 & 0.001873768 \\ 7.069362688 & 3.455381054 \\ 0.233748490 & 0.069387844 \\ & \\ 4.617319622 & 0.890776496 \\ -0.008062957 & 0.001681891 \\ 0.454190765 & 0.139146278 \\ 0.226598798 & 0.114381371\end{array}$

$\begin{array}{rr}5.58171 & 0.00000002 \\ -3.63680 & 0.00027605 \\ 2.04590 & 0.04076625 \\ 3.36872 & 0.00075517 \\ & \\ 5.18348 & 0.00000022 \\ -\mathbf{4 . 7 9 3 9 8} & \mathbf{0 . 0 0 0 0 0 1 6 4} \\ 3.26412 & 0.00109803 \\ 1.98108 & 0.04758215\end{array}$


Table 3. Country-by-Country EGARCH Estimates for IPG

Mean Equation: $\quad X_{i t}=D 60+D 70+D 80+D 9004+\beta_{i} \bar{X}_{t}+\gamma X_{i t-1}+h_{i t} \varepsilon_{i t}$

Variance Equation: $\operatorname{Ln}\left(h_{i t}^{2}\right)=D 60+D 70+D 80+D 9004+b \varepsilon_{i t-1}^{2}+c \operatorname{Ln}\left(h_{i t-1}^{2}\right)$

\begin{tabular}{|c|c|c|c|c|c|c|c|c|}
\hline \multirow[b]{3}{*}{ Country } & \multicolumn{4}{|c|}{ Mean Equation } & \multicolumn{4}{|c|}{ Variance Equation } \\
\hline & $\mathrm{D} 60$ & $\mathrm{D} 70$ & D80 & D9004 & D60 & $\mathrm{D} 70$ & $\mathrm{D} 80$ & D9004 \\
\hline & & & & & & & & \\
\hline Austria & -0.02 & 0.36 & 0.13 & 0.36 & 0.76 & -1.09 & -1.15 & -0.82 \\
\hline Belgium & 0.09 & 0.02 & 0.06 & 0.13 & -0.14 & 0.27 & 0.23 & 0.21 \\
\hline France & -0.01 & 0.24 & 0.07 & 0.07 & 1.27 & -2.35 & -2.72 & -3.01 \\
\hline Germany & 0.21 & -0.07 & 0.03 & 0.04 & 0.44 & -0.83 & -0.58 & -1.19 \\
\hline Greece & 0.70 & 0.63 & 0.22 & -0.04 & 0.51 & -0.53 & -0.30 & -0.29 \\
\hline Italy & 0.16 & 0.29 & 0.08 & 0.00 & 0.13 & 0.15 & -0.21 & -0.90 \\
\hline Netherlands & 0.50 & 0.14 & 0.12 & 0.10 & -0.17 & 0.44 & 0.91 & 0.62 \\
\hline Portugal & 0.35 & 0.67 & 0.41 & 0.10 & 0.61 & -0.56 & -0.84 & -0.89 \\
\hline Sweden & 0.17 & 0.04 & 0.08 & 0.20 & 1.10 & -1.68 & -0.67 & -2.30 \\
\hline U.K. & -0.01 & 0.04 & 0.07 & -0.03 & -0.83 & 1.59 & 1.00 & 0.40 \\
\hline Mean & 0.21 & 0.24 & 0.13 & 0.09 & 0.37 & -0.46 & -0.44 & -0.82 \\
\hline Variance & 0.06 & 0.07 & 0.01 & 0.01 & 0.40 & 1.28 & 1.15 & 1.34 \\
\hline
\end{tabular}


Table 4. Dependent Variables: Cross-Country Variance of IEDFs and Country IEDFs

$$
\begin{array}{ll}
\text { Panel A: } & \bar{\sigma}_{M}^{2}(t)=A_{0}+A_{1} t+\eta_{t} \\
\text { Panels B: } & \bar{\sigma}_{M}^{2}(t)=D 702+D 801+D 802+D 901+D 902+D 00+\eta_{t} \\
\text { Panels C: } & E D F_{i}(t)=D 702+D 801+D 802+D 901+D 902+D 00+\eta_{t}
\end{array}
$$

\begin{tabular}{|c|c|c|c|c|}
\hline$* * * *$ & $\underset{* * * * * * * * * * * * * *}{\operatorname{Coeff}}$ & 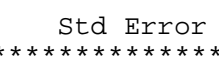 & $\begin{array}{c}\mathrm{T}-\mathrm{Stat} \\
* * \star * * * * *\end{array}$ & 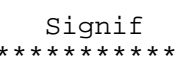 \\
\hline \multicolumn{5}{|l|}{ Panel A } \\
\hline A0 & 0.238763917 & 0.032929671 & 7.25072 & 0.00000000 \\
\hline A1 & -0.000240336 & 0.000106836 & -2.24957 & 0.02447599 \\
\hline \multicolumn{5}{|l|}{ Panel B } \\
\hline D702 & 0.1727069830 & 0.0193907237 & 8.90668 & 0.00000000 \\
\hline D 801 & 0.2497064481 & 0.0464092453 & 5.38053 & 0.00000007 \\
\hline D 802 & 0.1860275694 & 0.0201381090 & 9.23759 & 0.00000000 \\
\hline D901 & 0.1888773756 & 0.0223010268 & 8.46945 & 0.00000000 \\
\hline D 902 & 0.1544279148 & 0.0150023740 & 10.29357 & 0.00000000 \\
\hline D 00 & 0.1431732182 & 0.0150554668 & 9.50972 & 0.00000000 \\
\hline
\end{tabular}

\begin{tabular}{|c|c|c|c|c|c|c|}
\hline & d702 & d801 & d802 & d901 & d902 & doo \\
\hline AUSTRIA & 1.20645 & 1.10617 & 1.29210 & 1.16723 & 1.19304 & 1.20955 \\
\hline BELGIUM & 1.13181 & 1.17612 & 1.22143 & 1.22645 & 1.17590 & 1.26687 \\
\hline DENMARK & 1.11991 & 1.27833 & 1.22076 & 1.23424 & 1.26985 & 1.15297 \\
\hline FRANCE & 1.17015 & 1.19635 & 1.24437 & 1.28162 & 1.22491 & 1.20120 \\
\hline GERMANY & 1.30347 & 1.25389 & 1.14590 & 1.15146 & 1.12503 & 1.13513 \\
\hline IRELAND & 1.05380 & 1.03319 & 1.27659 & 1.26040 & 1.28902 & 1.19700 \\
\hline ITALY & 1.30551 & 1.26973 & 1.27198 & 1.28658 & 1.34620 & 1.24998 \\
\hline NETHERLANDS & 1.20677 & 1.20968 & 1.23937 & 1.24176 & 1.25930 & 1.15309 \\
\hline $\mathrm{U} . \mathrm{K}$. & 1.23885 & 1.25970 & 1.13021 & 1.20395 & 1.27444 & 1.26789 \\
\hline Mean & 1.19297 & 1.19813 & 1.22697 & 1.22819 & 1.23974 & 1.20374 \\
\hline Variance & 0.00704 & 0.00684 & 0.00315 & 0.00221 & 0.00449 & 0.00252 \\
\hline
\end{tabular}


Figure 2: Bank DDs
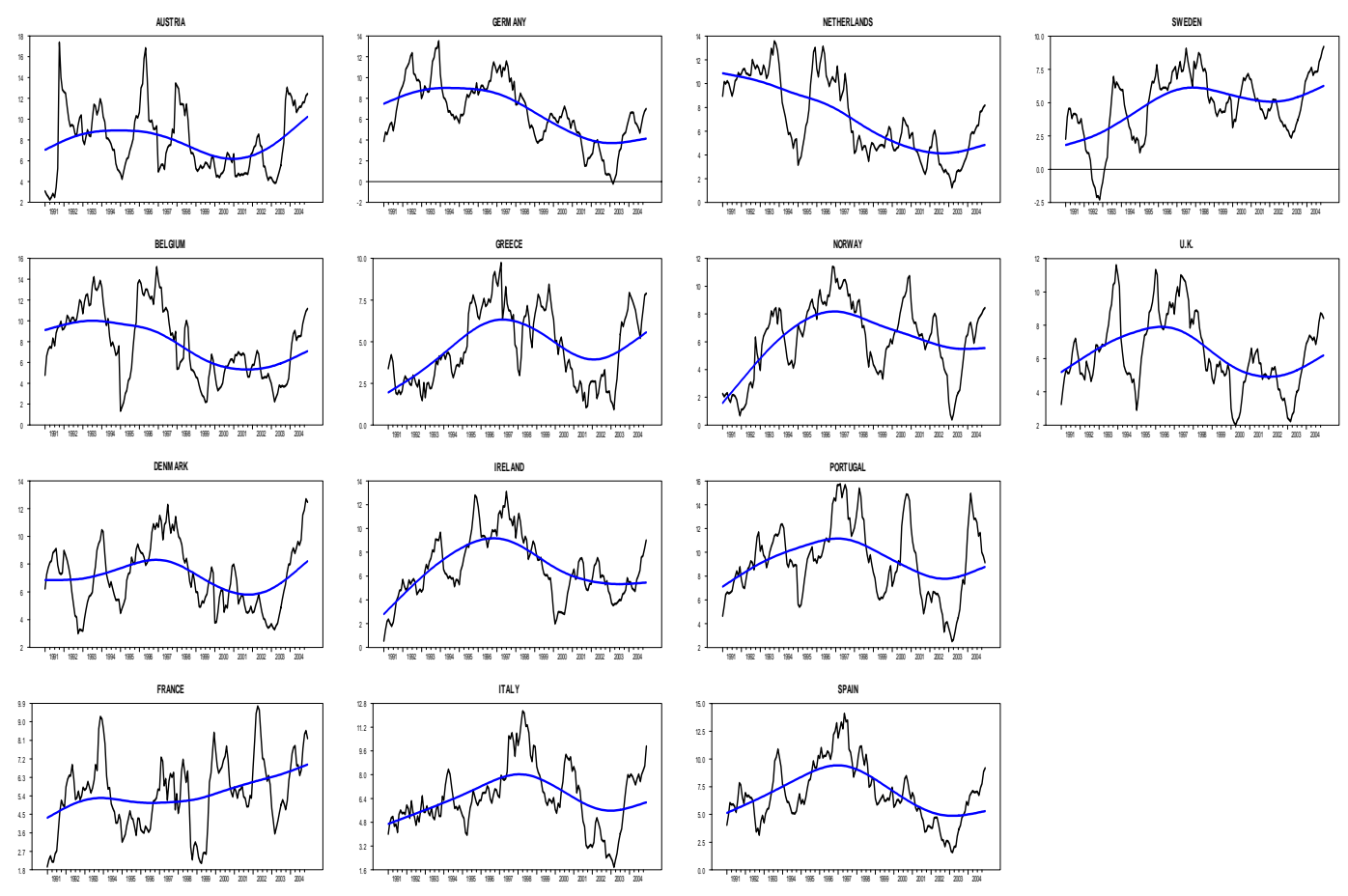

Figure 3: Insurance DDs
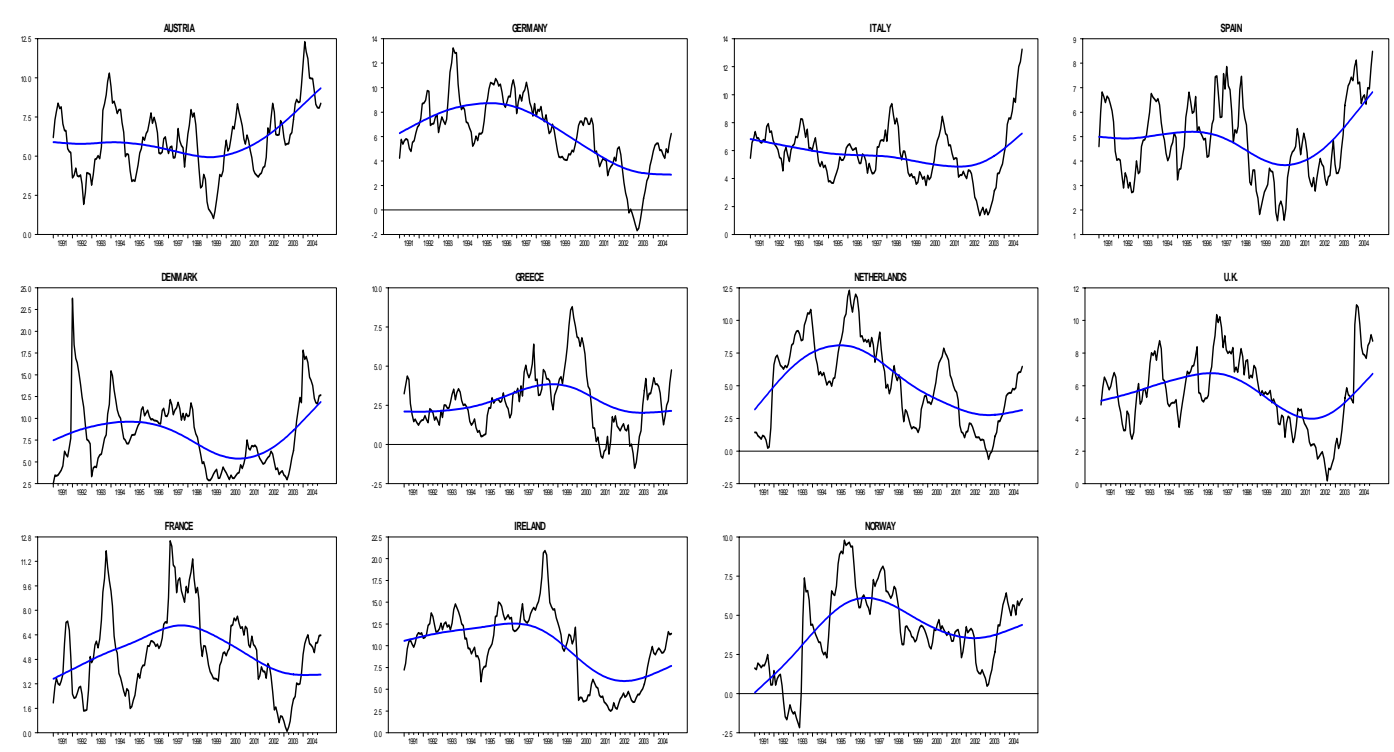
Table 5. Dependent Variables: Cross-Country Variance of Portfolios’ DDs

Mean Equation: $\quad \bar{\sigma}_{D D}^{2}(t)=A_{0}+A_{1} t+A_{2} Y_{t}^{2}+A_{3} \bar{\sigma}_{D D}^{2}(t-1)+H_{t} \eta_{t}$ Variance Equation: $\quad \log H_{t}^{2}=B_{0}+B_{1} t+B_{2} \eta_{t-1}^{2}+B_{3} \log H_{t-1}^{2}$

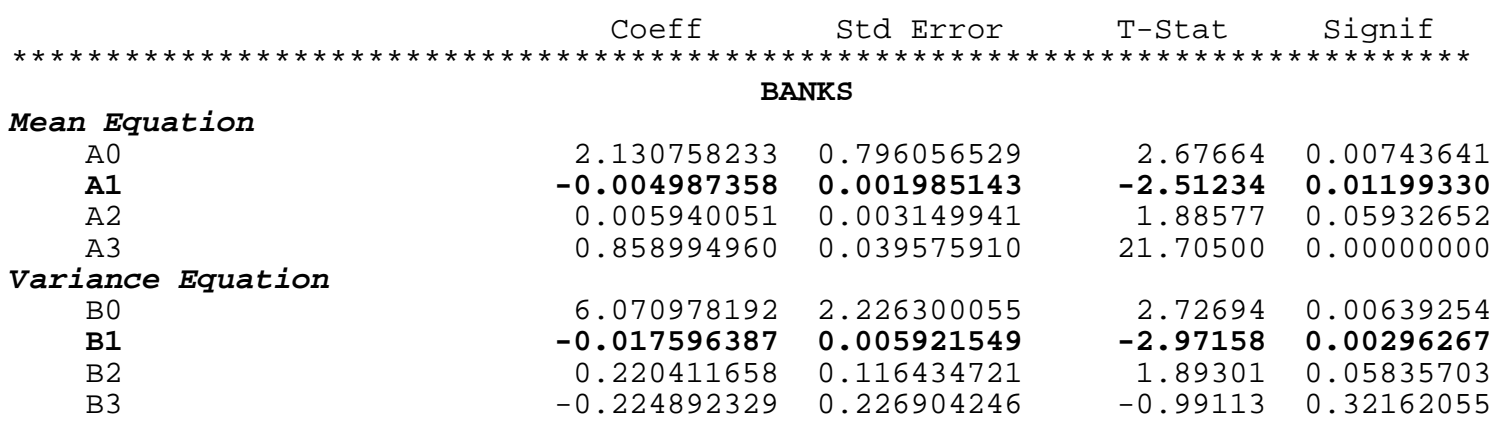

Mean Equation

A 0

A1

A2

A 3

Variance Equation

B0

B1

B2

B3
INSURANCE

$$
\begin{array}{r}
1.103339887 \\
0.003887521 \\
0.057381532 \\
0.719393328 \\
9.234640107 \\
-0.021483407 \\
0.010679293 \\
-0.470348664
\end{array}
$$
0.41360
0.78630
2.68954
6.92396
0.67916850
0.43169399
0.00715502
0.93653
$-0.90770$
0.02714
$-0.50244$
0.34900198
0.36403563
0.97834998
0.61536123 
Table 6. Dependent Variable: Banks DDs Changes

\begin{tabular}{|c|c|c|c|c|c|c|c|c|}
\hline & $\beta_{1}$ & $\beta_{11}$ & $\beta_{12}$ & $\beta_{13}$ & $\beta_{2}$ & $\beta_{21}$ & $\beta_{22}$ & $\beta_{23}$ \\
\hline $\begin{array}{l}\text { AUSTRIA } \\
\text { t-stat }\end{array}$ & $\begin{array}{l}0.22914 \\
1.12680\end{array}$ & $\begin{array}{l}0.19882 \\
0.48277\end{array}$ & $\begin{array}{l}0.24446 \\
0.74375\end{array}$ & $\begin{array}{l}0.19005 \\
0.86648\end{array}$ & $\begin{array}{l}3.06991 \\
0.90713\end{array}$ & $\begin{array}{l}-2.58253 \\
-0.31624\end{array}$ & $\begin{array}{l}5.08501 \\
0.88052\end{array}$ & $\begin{array}{l}4.14558 \\
2.02906\end{array}$ \\
\hline $\begin{array}{l}\text { BELGIUM } \\
\text { t-stat }\end{array}$ & $\begin{array}{l}-0.05524 \\
-0.44064\end{array}$ & $\begin{array}{l}-0.14530 \\
-0.83982\end{array}$ & $\begin{array}{l}-0.18260 \\
-0.48629\end{array}$ & $\begin{array}{l}0.12222 \\
0.89236\end{array}$ & $\begin{array}{l}6.79376 \\
3.71733\end{array}$ & $\begin{array}{l}7.18137 \\
2.21134\end{array}$ & $\begin{array}{l}6.00944 \\
1.41646\end{array}$ & $\begin{array}{l}7.22582 \\
4.12920\end{array}$ \\
\hline $\begin{array}{l}\text { DENMARK } \\
\text { t-stat }\end{array}$ & $\begin{array}{l}0.18350 \\
1.72894\end{array}$ & $\begin{array}{l}-0.02602 \\
-0.21526\end{array}$ & $\begin{array}{l}0.08777 \\
0.35315\end{array}$ & $\begin{array}{l}0.50247 \\
2.98560\end{array}$ & $\begin{array}{l}5.39206 \\
4.54716\end{array}$ & $\begin{array}{r}11.29102 \\
5.23163\end{array}$ & $\begin{array}{l}5.53111 \\
2.81885\end{array}$ & $\begin{array}{l}1.83205 \\
1.05308\end{array}$ \\
\hline $\begin{array}{l}\text { FRANCE } \\
\text { t-stat }\end{array}$ & $\begin{array}{l}-0.06485 \\
-0.86576\end{array}$ & $\begin{array}{l}-0.21530 \\
-2.08099\end{array}$ & $\begin{array}{l}-0.07057 \\
-0.37863\end{array}$ & $\begin{array}{l}0.06281 \\
0.58821\end{array}$ & $\begin{array}{l}8.51009 \\
6.68370\end{array}$ & $\begin{array}{l}6.23099 \\
2.43581\end{array}$ & $\begin{array}{r}10.61516 \\
5.36341\end{array}$ & $\begin{array}{l}7.25105 \\
4.64868\end{array}$ \\
\hline $\begin{array}{l}\text { GERMANY } \\
\text { t-stat }\end{array}$ & $\begin{array}{l}0.00863 \\
0.10507\end{array}$ & $\begin{array}{l}-0.08972 \\
-0.52650\end{array}$ & $\begin{array}{l}-0.12743 \\
-0.64834\end{array}$ & $\begin{array}{l}0.14603 \\
1.93410\end{array}$ & $\begin{array}{l}6.01768 \\
4.15413\end{array}$ & $\begin{array}{l}1.50707 \\
0.24985\end{array}$ & $\begin{array}{l}5.94823 \\
3.36277\end{array}$ & $\begin{array}{l}8.47721 \\
5.78293\end{array}$ \\
\hline $\begin{array}{l}\text { GREECE } \\
\text { t-stat }\end{array}$ & $\begin{array}{l}0.00882 \\
0.10323\end{array}$ & $\begin{array}{l}-0.10041 \\
-0.90929\end{array}$ & $\begin{array}{l}0.14396 \\
0.64083\end{array}$ & $\begin{array}{l}0.02024 \\
0.15302\end{array}$ & $\begin{array}{l}6.84393 \\
5.54959\end{array}$ & $\begin{array}{l}\mathbf{4 . 9 4 2 8 7} \\
2.61422\end{array}$ & $\begin{array}{l}9.23776 \\
5.00959\end{array}$ & $\begin{array}{l}5.07508 \\
2.54594\end{array}$ \\
\hline $\begin{array}{l}\text { IRELAND } \\
\text { t-stat }\end{array}$ & $\begin{array}{l}-0.08240 \\
-1.01429\end{array}$ & $\begin{array}{l}-0.26604 \\
-1.88952\end{array}$ & $\begin{array}{l}-0.08318 \\
-0.49246\end{array}$ & $\begin{array}{l}0.10216 \\
0.83259\end{array}$ & $\begin{array}{l}5.67918 \\
4.19292\end{array}$ & $\begin{array}{l}6.03562 \\
3.09929\end{array}$ & $\begin{array}{l}5.79232 \\
2.26681\end{array}$ & $\begin{array}{l}4.84149 \\
2.32658\end{array}$ \\
\hline $\begin{array}{l}\text { ITALY } \\
\text { t-stat }\end{array}$ & $\begin{array}{l}0.21024 \\
2.50871\end{array}$ & $\begin{array}{l}0.25366 \\
1.80220\end{array}$ & $\begin{array}{l}0.11337 \\
0.77431\end{array}$ & $\begin{array}{l}0.17804 \\
1.41244\end{array}$ & $\begin{array}{l}7.30423 \\
6.47755\end{array}$ & $\begin{array}{l}2.14074 \\
0.86133\end{array}$ & $\begin{array}{r}10.67059 \\
7.00629\end{array}$ & $\begin{array}{l}7.15589 \\
4.21428\end{array}$ \\
\hline $\begin{array}{l}\text { NETHERLANDS } \\
\text { t-stat }\end{array}$ & $\begin{array}{l}-0.02262 \\
-0.26792\end{array}$ & $\begin{array}{l}-0.23540 \\
-1.62760\end{array}$ & $\begin{array}{l}-0.03518 \\
-0.16432\end{array}$ & $\begin{array}{l}0.14693 \\
1.81176\end{array}$ & $\begin{array}{l}5.91218 \\
4.79348\end{array}$ & $\begin{array}{l}1.99414 \\
0.59233\end{array}$ & $\begin{array}{l}6.59478 \\
3.15099\end{array}$ & $\begin{array}{l}6.83980 \\
4.37547\end{array}$ \\
\hline $\begin{array}{l}\text { NORWAY } \\
\text { t-stat }\end{array}$ & $\begin{array}{l}0.17415 \\
1.95444\end{array}$ & $\begin{array}{l}0.20640 \\
1.09798\end{array}$ & $\begin{array}{l}0.10871 \\
0.72036\end{array}$ & $\begin{array}{l}0.18771 \\
1.61691\end{array}$ & $\begin{array}{l}5.42550 \\
4.36156\end{array}$ & $\begin{array}{l}5.60672 \\
1.73398\end{array}$ & $\begin{array}{l}5.62960 \\
2.78827\end{array}$ & $\begin{array}{l}5.31900 \\
3.66942\end{array}$ \\
\hline $\begin{array}{l}\text { PORTUGAL } \\
\text { t-stat }\end{array}$ & $\begin{array}{l}0.14310 \\
1.55419\end{array}$ & $\begin{array}{l}-0.14880 \\
-1.09203\end{array}$ & $\begin{array}{l}0.35741 \\
2.06801\end{array}$ & $\begin{array}{l}0.23421 \\
1.41386\end{array}$ & $\begin{array}{l}7.23641 \\
5.71466\end{array}$ & $\begin{array}{l}2.33354 \\
0.82094\end{array}$ & $\begin{array}{l}8.10958 \\
3.66198\end{array}$ & $\begin{array}{l}7.98958 \\
4.03926\end{array}$ \\
\hline $\begin{array}{l}\text { SPAIN } \\
t \text {-stat }\end{array}$ & $\begin{array}{l}-0.00595 \\
-0.07638\end{array}$ & $\begin{array}{l}-0.06114 \\
-0.45176\end{array}$ & $\begin{array}{l}-0.14175 \\
-0.78550\end{array}$ & $\begin{array}{l}0.15393 \\
1.52710\end{array}$ & $\begin{array}{l}8.99014 \\
6.44645\end{array}$ & $\begin{array}{r}10.51475 \\
2.56563\end{array}$ & $\begin{array}{l}9.79983 \\
4.43565\end{array}$ & $\begin{array}{l}7.39503 \\
4.20194\end{array}$ \\
\hline $\begin{array}{l}\text { SWEDEN } \\
\text { t-stat }\end{array}$ & $\begin{array}{l}0.11139 \\
1.44782\end{array}$ & $\begin{array}{l}-0.05850 \\
-0.47774\end{array}$ & $\begin{array}{l}0.01928 \\
0.11013\end{array}$ & $\begin{array}{l}0.35596 \\
3.77615\end{array}$ & $\begin{array}{l}5.62820 \\
4.85987\end{array}$ & $\begin{array}{l}7.54971 \\
3.18056\end{array}$ & $\begin{array}{l}6.35453 \\
2.92426\end{array}$ & $\begin{array}{l}3.66768 \\
3.14802\end{array}$ \\
\hline $\begin{array}{l}\text { U. } \mathbf{~} \\
\text { stat }\end{array}$ & $\begin{array}{l}-0.11513 \\
-1.39310\end{array}$ & $\begin{array}{l}-0.40599 \\
-2.93993\end{array}$ & $\begin{array}{l}-0.09382 \\
-0.62166\end{array}$ & $\begin{array}{l}0.15302 \\
1.18845\end{array}$ & $\begin{array}{l}4.95129 \\
4.43553\end{array}$ & $\begin{array}{l}5.10395 \\
2.00226\end{array}$ & $\begin{array}{l}5.11531 \\
2.62350\end{array}$ & $\begin{array}{l}3.94157 t \\
2.81685\end{array}$ \\
\hline
\end{tabular}


Table 7. Dependent Variable : Insurance DDs Changes

Models : (1) $\Delta \rho_{t}^{i}=\alpha+\beta_{1} F_{t}+\beta_{2} R_{t}+\gamma \Delta \rho_{t-1}^{i}+\varepsilon_{t}^{i}$; (2) $\Delta \rho_{t}^{i}=\alpha+\sum_{j=1}^{3} \beta_{1 j} I_{j} F_{t}+\sum_{j=1}^{3} \beta_{2 j} I_{j} R_{t}+\gamma \Delta \rho_{t-1}^{i}+\varepsilon_{t}^{i}$

\begin{tabular}{|c|c|c|c|c|c|c|c|c|}
\hline & $\beta_{1}$ & $\beta_{11}$ & $\beta_{12}$ & $\beta_{13}$ & $\beta_{2}$ & $\beta_{21}$ & $\beta_{22}$ & $\beta_{23}$ \\
\hline $\begin{array}{l}\text { AUSTRIA } \\
\text { t-stat }\end{array}$ & $\begin{array}{l}-0.07401 \\
-0.87164\end{array}$ & $\begin{array}{l}-0.13646 \\
-0.79823\end{array}$ & $\begin{array}{l}-0.02889 \\
-0.18099\end{array}$ & $\begin{array}{l}-0.05242 \\
-0.41560\end{array}$ & $\begin{array}{l}5.56877 \\
3.93998\end{array}$ & $\begin{array}{l}4.79820 \\
1.12355\end{array}$ & $\begin{array}{l}6.68891 \\
3.95795\end{array}$ & $\begin{array}{l}\mathbf{4} .74129 \\
2.21433\end{array}$ \\
\hline $\begin{array}{l}\text { DENMARK } \\
\text { t-stat }\end{array}$ & $\begin{array}{l}0.35582 \\
1.32135\end{array}$ & $\begin{array}{l}1.05606 \\
1.36990\end{array}$ & $\begin{array}{l}0.12418 \\
0.52799\end{array}$ & $\begin{array}{l}-0.00905 \\
-0.04400\end{array}$ & $\begin{array}{r}11.31496 \\
3.67787\end{array}$ & $\begin{array}{r}28.15192 \\
1.89994\end{array}$ & $\begin{array}{l}7.08159 \\
3.42040\end{array}$ & $\begin{array}{l}8.84322 \\
2.21464\end{array}$ \\
\hline $\begin{array}{l}\text { FRANCE } \\
\text { t-stat }\end{array}$ & $\begin{array}{l}-0.19178 \\
-2.11906\end{array}$ & $\begin{array}{l}-0.48789 \\
-2.58970\end{array}$ & $\begin{array}{l}-0.20667 \\
-1.10573\end{array}$ & $\begin{array}{l}0.08307 \\
0.89256\end{array}$ & $\begin{array}{r}10.62458 \\
7.15602\end{array}$ & $\begin{array}{l}8.60484 \\
2.15961\end{array}$ & $\begin{array}{r}12.58048 \\
4.77712\end{array}$ & $\begin{array}{l}9.19347 \\
5.59050\end{array}$ \\
\hline $\begin{array}{l}\text { GERMANY } \\
\text { t-stat }\end{array}$ & $\begin{array}{l}0.02595 \\
0.29904\end{array}$ & $\begin{array}{l}-0.03629 \\
-0.18959\end{array}$ & $\begin{array}{l}0.01163 \\
0.06824\end{array}$ & $\begin{array}{l}0.08253 \\
0.84674\end{array}$ & $\begin{array}{l}6.17503 \\
3.85809\end{array}$ & $\begin{array}{l}\mathbf{4} .73298 \\
0.77777\end{array}$ & $\begin{array}{l}3.90193 \\
1.72722\end{array}$ & $\begin{array}{l}9.01931 \\
6.90630\end{array}$ \\
\hline $\begin{array}{l}\text { GREECE } \\
\text { t-stat }\end{array}$ & $\begin{array}{l}-0.00128 \\
-0.01313\end{array}$ & $\begin{array}{l}-0.16637 \\
-1.81309\end{array}$ & $\begin{array}{l}0.31959 \\
1.48146\end{array}$ & $\begin{array}{l}-0.05217 \\
-0.33157\end{array}$ & $\begin{array}{l}5.78269 \\
4.71844\end{array}$ & $\begin{array}{l}4.96145 \\
2.88784\end{array}$ & $\begin{array}{l}5.78071 \\
2.51895\end{array}$ & $\begin{array}{l}5.30061 \\
2.65559\end{array}$ \\
\hline $\begin{array}{l}\text { IRELAND } \\
\text { t-stat }\end{array}$ & $\begin{array}{l}-0.00002 \\
-0.00143\end{array}$ & $\begin{array}{l}-0.12271 \\
-0.92617\end{array}$ & $\begin{array}{l}0.04893 \\
0.13156\end{array}$ & $\begin{array}{l}0.09791 \\
0.39044\end{array}$ & $\begin{array}{l}4.27298 \\
2.58317\end{array}$ & $\begin{array}{l}5.76075 \\
1.78139\end{array}$ & $\begin{array}{l}6.61989 \\
1.97196\end{array}$ & $\begin{array}{l}0.92890 \\
0.44966\end{array}$ \\
\hline $\begin{array}{l}\text { ITALY } \\
\text { t-stat }\end{array}$ & $\begin{array}{l}0.13099 \\
1.99638\end{array}$ & $\begin{array}{l}0.12708 \\
1.09772\end{array}$ & $\begin{array}{l}0.05859 \\
0.50392\end{array}$ & $\begin{array}{l}0.12922 \\
1.24325\end{array}$ & $\begin{array}{l}5.67917 \\
4.58143\end{array}$ & $\begin{array}{l}0.60276 \\
0.19621\end{array}$ & $\begin{array}{l}7.62463 \\
3.87340\end{array}$ & $\begin{array}{l}6.70161 \\
4.68354\end{array}$ \\
\hline $\begin{array}{l}\text { NETHERLANDS } \\
\text { t-stat }\end{array}$ & $\begin{array}{l}0.02564 \\
0.30738\end{array}$ & $\begin{array}{l}-0.14301 \\
-1.06652\end{array}$ & $\begin{array}{l}0.01596 \\
0.07301\end{array}$ & $\begin{array}{l}0.12346 \\
1.42235\end{array}$ & $\begin{array}{l}5.43702 \\
3.59210\end{array}$ & $\begin{array}{l}-1.57370 \\
-0.41880\end{array}$ & $\begin{array}{l}8.48470 \\
3.98888\end{array}$ & $\begin{array}{l}5.82751 \\
3.69937\end{array}$ \\
\hline $\begin{array}{l}\text { NORWAY } \\
t \text {-stat }\end{array}$ & $\begin{array}{l}0.04063 \\
0.46890\end{array}$ & $\begin{array}{l}0.00638 \\
0.04253\end{array}$ & $\begin{array}{l}0.08005 \\
0.41735\end{array}$ & $\begin{array}{l}0.08555 \\
0.73726\end{array}$ & $\begin{array}{l}5.45010 \\
4.95299\end{array}$ & $\begin{array}{l}8.69135 \\
2.80595\end{array}$ & $\begin{array}{l}\mathbf{4} .54006 \\
2.57227\end{array}$ & $\begin{array}{l}4.48679 \\
2.96369\end{array}$ \\
\hline $\begin{array}{l}\text { SPAIN } \\
\text { t-stat }\end{array}$ & $\begin{array}{l}0.02762 \\
0.39628\end{array}$ & $\begin{array}{l}-0.10887 \\
-1.16996\end{array}$ & $\begin{array}{l}0.12016 \\
0.75689\end{array}$ & $\begin{array}{l}0.09305 \\
0.84544\end{array}$ & $\begin{array}{l}5.97838 \\
5.60565\end{array}$ & $\begin{array}{l}5.90317 \\
4.09959\end{array}$ & $\begin{array}{l}7.39693 \\
3.59187\end{array}$ & $\begin{array}{l}4.33736 \\
3.03786\end{array}$ \\
\hline $\begin{array}{l}\text { U. } \mathbf{K} \text {. } \\
\text { t-stat }\end{array}$ & $\begin{array}{l}-0.14484 \\
-1.57067\end{array}$ & $\begin{array}{l}-0.28911 \\
-2.35482\end{array}$ & $\begin{array}{l}0.17216 \\
0.66822\end{array}$ & $\begin{array}{l}-0.19506 \\
-1.30092\end{array}$ & $\begin{array}{l}5.39866 \\
3.21487\end{array}$ & $\begin{array}{l}7.48984 \\
3.25397\end{array}$ & $\begin{array}{l}2.26799 \\
0.89055\end{array}$ & $\begin{array}{l}6.49323 \\
2.04962\end{array}$ \\
\hline
\end{tabular}


Appendix Table 1. Banks and Insurance Companies

\begin{tabular}{|c|c|c|c|c|c|}
\hline \multicolumn{6}{|c|}{$\begin{array}{l}\text { Total Assets, end } 2004 \\
\text { (In millions of euro) }\end{array}$} \\
\hline Austria & & Germany & & Italy & \\
\hline Banks & & Banks & & Banks & \\
\hline $\begin{array}{l}\text { BANK } \\
\text { AU.CREDITANSTALT }\end{array}$ & 145,680 & $\begin{array}{l}\text { BANKGESELLSCHAFT } \\
\text { BERLIN }\end{array}$ & 152,041 & UNICREDITO ITALIANO & 264,791 \\
\hline ERSTE BANK & 139,390 & $\begin{array}{l}\text { BAYER.HYPO-UND- } \\
\text { VBK. }\end{array}$ & 463,496 & SAN PAOLO IMI & 209,627 \\
\hline Insurance & & COMMERZBANK & 419,674 & CAPITALIA & 131,163 \\
\hline GENERALI HOLDING & 10,430 & DEUTSCHE BANK & 836,368 & BANCA INTESA & 273,181 \\
\hline UNIQA & 15,125 & Insurance & & $\begin{array}{l}\text { BANCA MONTE DEI } \\
\text { PASCHI }\end{array}$ & 128,662 \\
\hline WIENER STAEDT VZ & 12,525 & $\begin{array}{l}\text { ALLIANZ } \\
\text { AMB GENERALI HDG. }\end{array}$ & $\begin{array}{r}958,579 \\
85,632\end{array}$ & $\begin{array}{l}\text { BCA.NAZ.LAVORO } \\
\text { Insurance }\end{array}$ & 78,111 \\
\hline Belgium & & AXA KONZERN & 38,438 & $\begin{array}{l}\text { CATTOLICA } \\
\text { ASSICURAZIONI }\end{array}$ & 14,773 \\
\hline Banks & & AXA VERSICHERUNG & 7,219 & FONDIARIA-SAI & 31,381 \\
\hline ALMANIJ & $259,629 *$ & $\begin{array}{l}\text { DBV-WINTERTHUR } \\
\text { HOLDING }\end{array}$ & 22,398 & GENERALI & 252,542 \\
\hline DEXIA & 349,463 & ERGO VERSICHERUNG & 108,988 & MILANO ASSIC. & 9,804 \\
\hline FORTIS (BRU) & 521,524 & GERLING & 4,327 & $\begin{array}{l}\text { PREMAFIN-HLDG.DI } \\
\text { PART. }\end{array}$ & 31,493 \\
\hline \multirow[t]{2}{*}{ KBC BKVS.HDG. } & 225,587 & HANNOVER RUCK. & 30,615 & RAS & 66,229 \\
\hline & & KOELN.RUCK. & 9,390 & UNIPOL & 32,201 \\
\hline Denmark & & $\begin{array}{l}\text { KOELN.VERWALT.GES } \\
\text { ELL. }\end{array}$ & 69 & & \\
\hline Banks & & MLP & 2,378 & Netherlands & \\
\hline DANSKE BANK & 248,949 & MUNCH.RUCK.REGD. & 203,501 & Banks & \\
\hline JYSKE BANK & 16,687 & $\begin{array}{l}\text { WUESTENROT \& } \\
\text { WUERTT. }\end{array}$ & 54,380 & ABN AMRO HOLDING & 607,263 \\
\hline SYDBANK & 10,453 & & & FORTIS (AMS) & 521,524 \\
\hline Insurance & & Greece & & Insurance & \\
\hline ALM BRAND & 2,897 & Banks & & ING GROEP CERTS. & 866,201 \\
\hline CODAN & 5,358 & ALPHA BANK & 32,917 & & \\
\hline \multirow[t]{2}{*}{ TOPDANMARK } & 4,516 & BANK OF GREECE & 32,810 & Norway & \\
\hline & & BANK OF PIRAEUS & 16,591 & Banks & \\
\hline France & & $\begin{array}{l}\text { EFG EUROBANK } \\
\text { ERGASIAS }\end{array}$ & 31,760 & DNB NOR & 86,097 \\
\hline Banks & & $\begin{array}{l}\text { EMPORIKI BK.OF } \\
\text { GREECE }\end{array}$ & 18,236 & $\begin{array}{l}\text { SPAREBANKEN } \\
\text { ROGALAND }\end{array}$ & 7,152 \\
\hline BNP PARIBAS & 905,001 & NAT.BK.OF GREECE & 52,877 & Insurance & \\
\hline CREDIT AGRICOLE & 814,654 & Insurance & & STOREBRAND & 20,871 \\
\hline SOCIETE GENERALE & 600,897 & $\begin{array}{l}\text { ETHNIKI GREEK GEN } \\
\text { IN CO }\end{array}$ & 1,621 & & \\
\hline Insurance & & & & Portugal & \\
\hline AGF-ASR.GL.DE FRN. & 103,549 & Ireland & & Banks & \\
\hline APRIL GROUP & 419 & Banks & & BANCO BPI & 26,166 \\
\hline AXA & 440,744 & ALLIED IRISH BANKS & 102,042 & $\begin{array}{l}\text { BNC.ESPR.SANTO } \\
\text { (BESCL)R }\end{array}$ & 45,894 \\
\hline EULER HERMES & 5,716 & ANG.IR.BK. & 34,305 & BNC.TOTTA \& ACORES & $28,824 *$ \\
\hline FINAXA & 4,973 & BANK OF IRELAND & 106,431 & BCP R & 71,678 \\
\hline \multirow[t]{2}{*}{ SCOR } & 12,542 & Insurance & & & \\
\hline & & FBD HOLDINGS & 1,394 & & \\
\hline
\end{tabular}


Appendix Table 1. Banks (concluded)

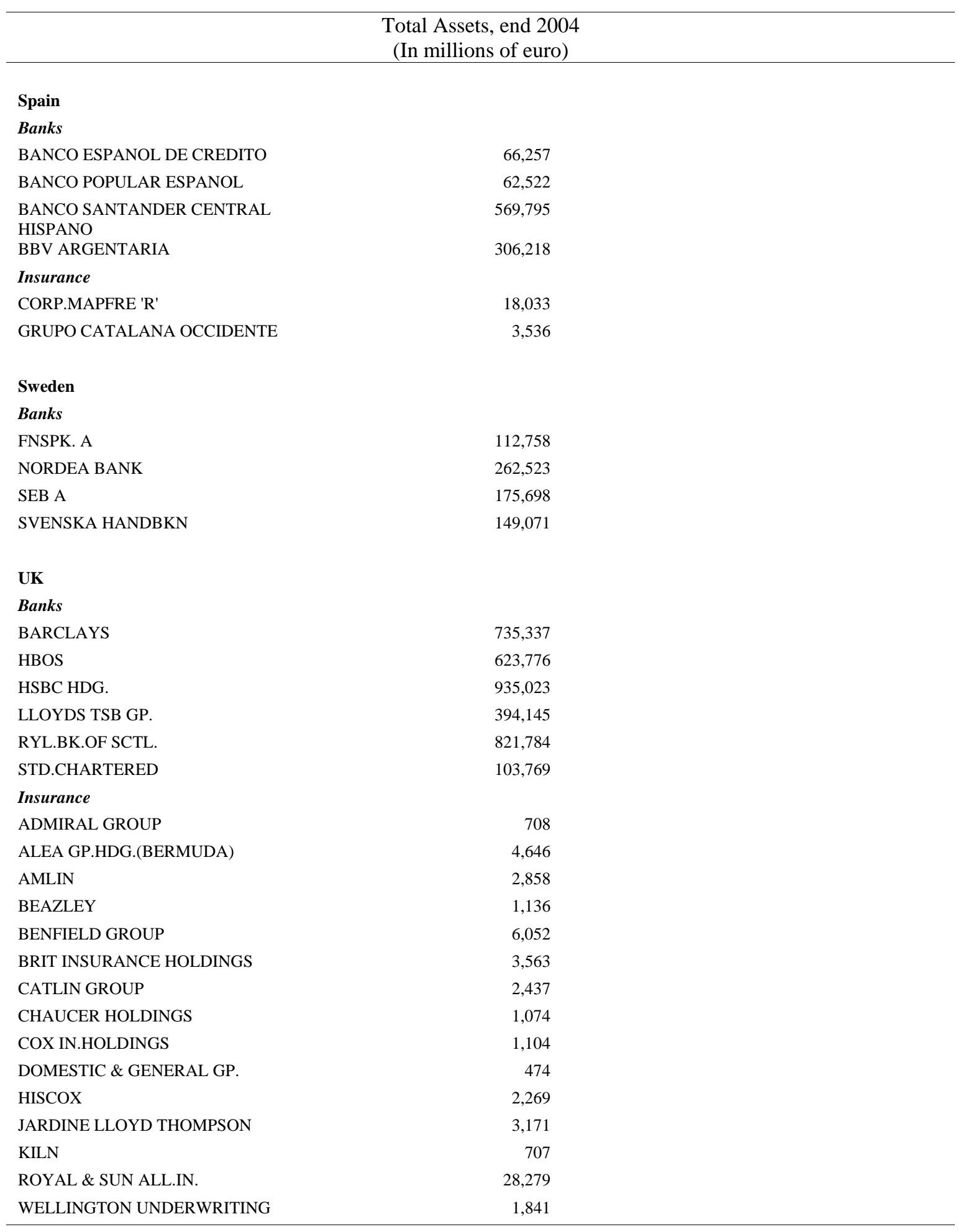




\section{REFERENCES}

Adam, Klause, Tullio Jappelli, Annamaria Menichini, Mario Padula, and Marco Pagano, 2002, “Analyze, Compare and Apply Alternative Indicators and Monitoring Methodologies to Measure the Evolution of Capital Market Integration in the European Union", Report to the European Commission (Brussels: European Commission).

Adjaouté, Kpate, and Jean-Pierre Danthine, 2004, "Equity Returns and Integration: Is Europe Changing?" Oxford Review of Economic Policy, Vol. 20, No. 4, pp. 555-70.

Arora, Navneet, Jeffrey R. Bohn and Fanlin Zhu, 2005, "Reduced Form versus Structural Models of Credit Risk: A Case Study of Three Models," Moody's KMV White Paper, February,(New York: Moody's).

Artis, Michael J., 2003, "Is There A European Business Cycle?" CESifo Working Paper Series No. 1053, (Munich: CESifo)

Barros, Pedro Pita, Erik Berglöf, Paolo Fulghieri, Jordi Gual, Colin Mayer, and Xavier Vives, 2005, "Integration of European Banking: The Way Forward," CEPR, MED 2.

Baele, Lieven, Annalisa Ferrando, Peter Hördahl, Elizaveta Krylova, and Cyril Monnet, 2004, "Measuring Financial Integration in the Euro Area," Oxford Review of Economic Policy, Vol. 20, No. 4, pp. 509-530.

Bekaert, Geert, Robert J. Hodrick and Xiaoyan Zhang, 2005, "International Stock Return Comovements," NBER Working Paper No. 11906, (Cambridge: NBER).

Black, F., and M. Scholes, 1973, "The Pricing of Options and Corporate Liabilities," Journal of Political Economy, Vol. 81, No. 3, pp. 637-54.

De Nicolò, Gianni, Robert Corker, Alexander Tieman and Jan Willem Van-derVossen, 2005a, "European Financial Integration, Stability and Supervision, IMF Country Report 05/266, August, pp. 113-146 (Washington: International Monetary Fund).

De Nicolò, Gianni, Alexander Tieman, and Robert Corker, 2005, "Large Banking Groups and Financial System Soundness”, IMF Country Report 05/116, March, pp. 102-111 (Washington: International Monetary Fund).

De Nicolò, Gianni, Phillip Bartholomew, Jahanara Zaman and Mary Zephirin, 2004, "Bank Consolidation, Internationalization and Conglomeration: Trends and Implications for Financial Risk," Financial Markets, Institutions \& Instruments, Vol. 13, No. 4, pp. 173-217. 
De Nicolò, Gianni, Peter Hayward, and Ashok Vir Bhatia, 2004, "U.S. Large Complex Banking Groups: Business Strategies, Risks and Surveillance Issues," IMF Country Report 04/228, July, pp. 72-86 (Washington: International Monetary Fund).

De Nicolò, Gianni and Myron Kwast, 2002, "Financial Risk and Consolidation: Are They Related?” Journal of Banking and Finance, Vol. 26, No. 5, pp. 861-880.

Duan, Jin-Chuan, Genevieve Gauthier and Jean-Guy Simonato, 2004, "On the Equivalence of the KMV and Maximum Likelihood Methods for Structural Credit Risk Models" (unpublished; Toronto: University of Toronto).

European Central Bank, 2004, "Accounting for the Resilience of the EU Banking Sector," Monthly Bulletin, April (Frankfurt European Central Bank).

Flood, Robert, and Andrew Rose, 2005, "Estimating the Expected Marginal Rate of Substitution: A Systematic Exploitation of Idiosyncratic Risk," Journal of Monetary Economics, Vol. 52, No.5, pp. 951-969.

Gropp, R.E., J. Vesala, and G. Vulpes, 2006, "Equity and Bond Market Signals as Leading Indicators of Bank Fragility," Journal of Money, Credit and Banking, Vol.32, No.2, pp. 399-428.

Hartmann, Philipp, Stefan Straetsman, and Casper de Vries, 2005, "Banking System Stability: A Cross-Atlantic Perspective,” Working Paper No. 527, September (Frankfurt: European Central Bank).

Houston, Joel F., and Kevin J Stiroh, 2006, "Three Decades of Financial Sector Risk," U.S. Financial Holding Companies," July (unpublished; New York: Federal Reserve Bank of New York).

Kose, Ayhan, Christopher Otrok, and Charles Whiteman, "Understanding the Evolution of World Business Cycles”, IMF Working Paper 05/211, November (Washington: International Monetary Fund).

Krainer, J. and J.A. Lopez, 2001, "Incorporating Equity Market Information into Supervisory Monitoring Models," FRBSF Working Paper 2001-14 (San Francisco: Federal Reserve Bank).

Lumsdaine, Robert L. and Eswar S. Prasad, 2003, "Identifying the Common Component of International Economic Fluctuations: A New Approach," Economic Journal, Vol. 113 (January), pp.101-127.

Marshall, David, 2005, "Comment on Estimating the Expected Marginal Rate of Substitution”, Journal of Monetary Economics, Vol. 52, No. 5, pp. 971-979. 
Merton, R.C., 1974, "On the Pricing of Corporate Debt: The Risk Structure of Interest Rates," Journal of Finance, Vol. 29, No. 2, pp. 449-70.

Ravn, Morten O. and Harald Uhlig, 2002, "On Adjusting the Hodrick-Prescott Filter for the Frequency of Observations," Review of Economics and Statistics, Vol. 84, No. 2, pp. 371-76.

Solnik, Bruno, and Jacques Roulet, 2000, "Dispersion as Cross-Sectional Correlation," Financial Analyst Journal, Vol. 56, No. 1, pp. 54-61.

Stiroh, Kevin J, 2004, "Diversification in Banking: Is Noninterest Income the Answer?" Journal of Money, Credit and Banking, Vol. 36, No. 5, pp. 853-882.

Stiroh, Kevin J, and Adrienne Rumble, 2006, "The Dark Side of Diversification: The Case of U.S. Financial Holding Companies,” Journal of Banking and Finance, Vol. 30, No. 8, pp 2131-2161.

Stock, James H., and Mark W. Watson, 2005, "Understanding Changes in International Business Cycle Dynamics," Journal of the European Economic Association, Vol. 3, No. 5, September, pp. 968-1006.

Tarashev, Nikola A., 2005, “An Empirical Evaluation of Structural Credit Risk Models”, BIS Working Paper, No. 179, July, (Basel: Bank for International Settlements).

Vassalou, M., and Y. Xing, 2004, "Default Risk in Equity Returns," Journal of Finance, Vol. 59, No. 2, pp. 831-68. 